\author{
Ткачук Г.О. \\ кандидат економічних наук, доцент \\ кафедра обліку та аудиту \\ Одеська національна академія харчових технологій \\ вул. Канатна, 112, м. Одеса, Україна, 65039 \\ E-mail: talla2007@ukr.net
}

\title{
ОБЛІКОВО-АНАЛІТИЧНЕ ЗАБЕЗПЕЧЕННЯ КАДРОВОЇ БЕЗПЕКИ ПІДПРИЄМСТВА
}

Проведена систематизація наукових підходів до визначення категорії «кадрова безпека». На підставі аналізу джерел визначено поняття склад основних кадрових загроз. Систематизовано види та основні напрямки кадрової політики. Виділено види обліково-аналітичного забезпечення кадрової політики. Запропоновано склад інформаційно-кадрового забезпечення.

Ключові слова: фрінансово-економічна безпека, кадрова безпека, обліково-аналітичне забезпечення, кадрові загрози, кадрова політика, інформаційно-кадрове забезпечення.

This work is licensed under a Creative Commons Attribution 4.0 International License http://creativecommons.org/licenses/by/4.0/

Постановка проблеми та її зв'язок з важливими науковими та практичними завданнями. Кадрова безпека - основна функціональна складова економічної безпеки підприємства, яка передбачає збереження та розвиток інтелектуального потенціалу підприємства, ефективне управління персоналом. Структура та якість кадрового складу в харчовій галузі промисловості впливають на всі аспекти його діяльності, а також невід'ємно пов'язані із економічною безпекою. Адже порушення працівниками підприємства трудової дисципліни, розкрадання або неефективне використання ресурсів, розголошення інформації, яка складає комерційну таємницю - створюють загрозу майну, репутації та безпеці компанії.

За результатами статистики близько $51 \%$ випадків економічних злочинів здійснюють співробітники компаній, а ефективна організація роботи щодо забезпечення кадрової безпеки може майже на $60 \%$ знизити прямі та передбачити непрямі збитки фірми, пов'язані з людським фактором [1].

Вітчизняні та зарубіжні спеціалісти вважають, що майже $80 \%$ збитків міжнародних компаній спричинені внаслідок незаконних та непрофесійних дій власних співробітників [2].

У зв'язку із вищезазначеним можна зробити висновок щодо необхідності забезпечення кадрової безпеки, в т.ч. обліково-аналітичного, на будь-якому підприємстві.

Проблеми кадрової безпеки переймаються такі науковці як Алавердов А.Р., Баглей Д.Ю., Калініченко Л.Л., Логінова Н.І., Мирющенко А.Л., Чумарін І.Г., Шаваєв А.Г. тощо.

В свою чергу, питаннями формування обліково-аналітичного забезпечення займаються на сучасному етапі розвитку економіки цілий ряд науковців: Гнилицька Л.В., Тринька Л.Я., Труш В.С., Яцен- ко В.Ф., Журавльова Т.В., Бушнова С.В., Давидюк Т.В., Галузіна С.М. та інші.

Аналіз останніх досліджень та публікацій дає змогу прийти до висновку, що поза увагою вищевказаних науковців залишаються проблеми та особливості облікового і аналітичного забезпечення економічної безпеки у процесі формування кадрової політики підприємства.

Формулювання цілей дослідження. В даній статі поставлено та вирішено наступні завдання: визначити склад кадрових загроз економічній безпеці підприємства; виділити види та основні напрямки кадрової політики підприємства; виділити види обліково-аналітичного забезпечення кадрової політики та склад інформаційно-кадрового забезпечення.

Виклад основних результатів та їх обгрунтування. Згідно 3 даними порталу Content Security, наявні у світі внутрішні та зовнішні загрози розподіляються таким чином: розголошення інформації (зайва балакучість праівників) (32\%); несанкціонований доступ до інформації шляхом підкупу і схиляння до співпраці з боку конкурентів (24\%); відсутність в компанії належного нагляду до конфіденційності інформації (14\%); традиційний обмін виробничим досвідом (12\%); безконтрольне використання інформаційних систем (8\%). [3]

Вважаємо, що склад основних кадрових загроз на сучасному підприємстві має ширшу палітру, оскільки пов'язаний не тільки із витоком інформації, але й $з$ якістю праці, кваліфікацією робітників, наявністю творчого потенціалу тощо. Такими загрозами на підприємстві можуть бути:

- втрати, пов'язані із плинністю кадрів;

- витік конфіденційної інформації;

- помилки із-за низької кваліфікації співробітників; 
помилки, пов'язані із високим ступенем стомлюваності та монотонності праці;

- відсутність наукової організації праці;

- наявність професійних захворювань;
- незацікавленість результатами роботи;

- відсутність професійного та кар'єрного росту.

В табл. 1 здійснено систематизацію підходів до трактування категорії «кадрова безпека».

Таблиця 1

Зміст категорії «кадрова безпека»*

\begin{tabular}{|c|c|}
\hline Автор & Зміст категорії \\
\hline Алавердов А.Р. & $\begin{array}{l}\text { Кадрова безпека - поточна та перспективна захищеність від загроз майнового та } \\
\text { немайнового характеру [4] }\end{array}$ \\
\hline Баглей Д.Ю. & $\begin{array}{l}\text { Кадрова безпека - стан захищеності господарського суб'єкта від кадрових небез- } \\
\text { пек і загроз, механізмом забезпечення цього стану є ефективне управління персо- } \\
\text { налом [5] }\end{array}$ \\
\hline Егоров С.С. & $\begin{array}{l}\text { Кадрова безпека - захищеність людських ресурсів від зовнішніх та внутрішніх } \\
\text { загроз, направлених на послаблення економічного, наукового та духовно- } \\
\text { морального потенціалу та включає в себе безпеку трудових ресурсів, інтелектуа- } \\
\text { льну безпеку, надійність персоналу у вищій ланці управління, лояльність співробі- } \\
\text { тників [6] }\end{array}$ \\
\hline Гречішкіна А.А. & $\begin{array}{l}\text { Кадрова безпека - процес попередження, запобігання і усунення ризиків та загроз } \\
\text { які виникають з боку персоналу з метою створення умов для стабільного функціо- } \\
\text { нування і розвитку підприєства [7] }\end{array}$ \\
\hline Гончаренко Л.П. & $\begin{array}{l}\text { Кадрова безпека - захищеність суспільно-прогресивних інтересів організації по } \\
\text { розвитку та удосконалення іії людського потенціалу, підтримки ефективної систе- } \\
\text { ми управління системи управління людськими ресурсами та мінімізації ризиків } \\
\text { компанії, пов’язаних з ії кадровою складовою [8] }\end{array}$ \\
\hline Джобава А.М. & $\begin{array}{l}\text { Кадрова безпека - сукупність заходів, спрямованих на запобігання протиправним } \\
\text { діям або сприяння їм з боку персоналу підприємства [9] }\end{array}$ \\
\hline Калініченко Л.Л. & $\begin{array}{l}\text { Кадрова безпека - це такий стан індивідуумів, колективу підприємства, його люд- } \\
\text { ського потенціалу та системи управління персоналом при якому забезпечується } \\
\text { ефективне використання економічного потенціалу та розвиток підприємства [10] }\end{array}$ \\
\hline Кафидов В.В. & $\begin{array}{l}\text { Кадрова безпека - процесс запобігання негативного впливу на економічну безпеку } \\
\text { підприємства за рахунок ризиків та загроз, пов'язаних із персоналом, його інтеле- } \\
\text { ктуальним потенціалом та трудовими відносинами в цілому [11] }\end{array}$ \\
\hline Кібанов А.Я. & $\begin{array}{l}\text { Кадрова безпека - це генеральний напрямок кадрової роботи, сукупність принци- } \\
\text { пів, методів, форм організаційного механізму з опрацювання цілей, завдань, спря- } \\
\text { мованих на збереження. Зміцнення й розвиток кадрового потенціалу, на створення } \\
\text { відповідального і високопродуктивного згуртованого колективу, здатного вчасно } \\
\text { реагувати на постійно мінливі вимоги ринку з урахуванням стратегії розвитку під- } \\
\text { приємства [12] }\end{array}$ \\
\hline Кириченко О.М. & $\begin{array}{l}\text { Кадрова безпека - це процес запобігання впливів на економічну безпеку підпри- } \\
\text { ємства за допомогою ліквідації чи зниження ризиків і різноманітних загроз, що } \\
\text { пов’язані } з \text { персоналом, його інтелектуальним потенціалом і трудовими відноси- } \\
\text { нами загалом [13] }\end{array}$ \\
\hline Лащенко О.Ю. & $\begin{array}{l}\text { Кадрова безпека - це характеристика стану економічної системи, при якому відбу- } \\
\text { вається ефективне функціонування всіх ії функціональних складових, забезпечен- } \\
\text { ня захищеності та здатність протистоянь внутрішнім і зовнішнім впливам і загро- } \\
\text { зам пов'язаних з персоналом, змістовний та структурний аналіз, діагностика та } \\
\text { прогнозування впливу діяльності персоналу на внутрішні та зовнішні показники } \\
\text { вказаної економічної системи [14] }\end{array}$ \\
\hline Литовченко О.Ю. & $\begin{array}{l}\text { Кадрова безпека - сукупність управлінських заходів, пов’язаних з ефективним } \\
\text { формуванням та використанням кадрового потенціалу підприємства з метою за- } \\
\text { безпечення та підтримки економічної стійкості та результативності господарської } \\
\text { діяльності підприємства [15] }\end{array}$ \\
\hline Логінова Н.І. & $\begin{array}{l}\text { Кадрова безпека підприємства - це найбільш важлива складова економічної без- } \\
\text { пеки підприємства, яка має на меті виявлення, знешкодження, запобігання, відве- } \\
\text { рнення та попередження загроз, небезпек і ризиків, які спрямовані на персонал та } \\
\text { його інтелектуальний потенціал, і ті, які йдуть безпосередньо від нього, що по- } \\
\text { винно проявлятися в системі управління трудовими ресурсами та в кадровій полі- } \\
\text { тиці підприємства [16] }\end{array}$ \\
\hline
\end{tabular}


Продовження табл.1

\begin{tabular}{|c|c|}
\hline Автор & Зміст категорії \\
\hline $\begin{array}{l}\text { Мехеда Н.Г., } \\
\text { Маренич А.І. }\end{array}$ & $\begin{array}{l}\text { Кадрова безпека - комбінація таких складових частин як безпека життєдіяльності, } \\
\text { соціально-мотиваційна, професійна та антиконфліктна безпека ризиків компанії, } \\
\text { пов’язаних із її складовою [17] }\end{array}$ \\
\hline $\begin{array}{l}\text { Мойсеєнко I.П., } \\
\text { Марченко О.М. }\end{array}$ & $\begin{array}{l}\text { Інтелектуально-кадрова безпека відображає забезпеченість підприємства управ- } \\
\text { лінським та промислово-виробничим персоналом, рівень плинності кадрів на під- } \\
\text { приємстві, достатність їх освітньо-кваліфікаційного рівня, захищеність від пере- } \\
\text { манювання працівників конкурентами [18] }\end{array}$ \\
\hline Мирющенко А.Л. & $\begin{array}{l}\text { Кадрова безпека - діяльність із створення умов функціонування компанії, за яких } \\
\text { забезпечується гарантована законодавством захищеність інтересів компанії від } \\
\text { ризиків та загроз, пов’язаних із власним персоналом [19] }\end{array}$ \\
\hline Митрофанов А.А. & $\begin{array}{l}\text { Кадрова безпека - це таке становище організації як соціальної спільноти й індиві- } \\
\text { да в ній, за якого вплив на них з боку природного, економічного й соціального } \\
\text { середовищ, а також внутрішнього середовища самої людини не здатні заподіяти } \\
\text { шкоди [20] }\end{array}$ \\
\hline Назарова Г.О. & $\begin{array}{l}\text { Кадрова безпека - це діяльність щодо створення умов для стабільного функціону- } \\
\text { вання й розвитку компанії, за яких забезпечують гарантовану законодавством за- } \\
\text { хищеність інтересів компанії та власників від ризиків і загроз, пов'язаних із пер- } \\
\text { соналом [21] }\end{array}$ \\
\hline Петров M.I. & $\begin{array}{l}\text { Кадрова безпека - це таке становище організації як соціальної спільності й індиві- } \\
\text { да в ній, за якого вплив на них із боку природного, економічного й соціального } \\
\text { середовищ, а також внутрішнього середовища самої людини не здатні заподіяти } \\
\text { шкоди [22] }\end{array}$ \\
\hline Чаплигіна Ю.С. & $\begin{array}{l}\text { Кадрова безпека - складова економічної безпеки підприємства, яка надає кількіс- } \\
\text { но-якісну характеристику стану захищеності підприємства від внутрішніх та зов- } \\
\text { нішніх загроз та ризиків, пов’язаних з персоналом [23] }\end{array}$ \\
\hline Чумарін І.Г. & $\begin{array}{l}\text { Процес запобігання негативним впливам на економічну безпеку підприємства за } \\
\text { рахунок ризиків і загроз, пов'язаних з персоналом, його інтелектуальним потенці- } \\
\text { алом та трудовими відносинами в цілому [24] }\end{array}$ \\
\hline Шаваєв А.Г. & $\begin{array}{l}\text { Кадрова безпека - стан захищеності суспільно-прогресивних інтересів організації } \\
\text { з розвитку й удосконалення її людського капіталу, підтримки ефективної системи } \\
\text { управління людськими ресурсами й мінімізації ризиків компанії, пов'язаних із іiі } \\
\text { складовою [25] }\end{array}$ \\
\hline Швець Н.К. & $\begin{array}{l}\text { Кадрова безпека - стан захищеності компанії від ризиків та загроз, пов’язаних із } \\
\text { персоналом [1] }\end{array}$ \\
\hline Шегельман I.P. & $\begin{array}{l}\text { Кадрова безпека - найважливіший фактор безпеки усіх сфер діяльності підприєм- } \\
\text { ства, нехтування яким здатне не лише нанести серйозну шкоду підприємству, але } \\
\text { й зруйнувати його економічну безпеку [26] }\end{array}$ \\
\hline
\end{tabular}

*систематизовано автором за аналізом джерел

Аналізуючи сутність кадрової безпеки підприємства, доцільно відокремити пов'язані з нею ключові проблеми [27]:

- розробка мотиваційних схем та схем оплати праці,

- ліквідація збитків, пов'язаних з трудовими спорами,

- аналіз ситуації конкурентів,

- аналіз ринку праці в регіоні,

- робота з кадровим резервом,

- оцінка компанії чи організації як роботода-

ВцЯ,

- способи проектування кар'єри,

- підвищення лояльності та відповідальності співробітників тощо.
Велика кількість вищезазначених проблем може бути ліквідована або зведена до мінімуму за наявності продуманої дієвої кадрової політики підприємства.

Кадрова політика підприємства - це система принципів і правил, за якими діють іiі працівники у внутрішньому і зовнішньому середовищі у відповідності з концепцією розвитку організації.

Кадрова політика може бути активною, пасивною, реактивною, превентивною та авантюристичною.

В табл. 2 систематизовано види кадрової політики підприємства та наведена їх характеристика, в табл. 3 - показано основні напрями кадрової політики за ступенем відкритості формування кадрового складу (відкриті та закриті) [28]. 
Види кадрової політики підприємства за рівнем впливу на неї управлінського персоналу*

\begin{tabular}{|c|c|}
\hline $\begin{array}{c}\text { Види кадрової } \\
\text { політики }\end{array}$ & Характеристика \\
\hline $\begin{array}{l}\text { 1.Активна кадрова } \\
\text { політика }\end{array}$ & $\begin{array}{l}\text { - керівництво підприємства має не тільки прогнози, а й засоби впливу на ситуацію; } \\
\text { - кадрова служба розробляє антикризові кадрові програми, здійснює моніторинг ситуа- } \\
\text { ції, регулює виконання програм відповідно до внутрішньої та зовнішньої ситуацій; } \\
\text { - керівництво підприємств має якісні програми кадрової роботи з варіантами їх реаліза- } \\
\text { ції при різних ситуаціях }\end{array}$ \\
\hline $\begin{array}{l}\text { 2.Пасивна кадрова } \\
\text { політика }\end{array}$ & $\begin{array}{l}\text { - керівництво підприємств немає чіткої програми дій відносно персоналу, а кадрова } \\
\text { робота полягає в усуненні негативних наслідків; } \\
\text { - відсутність прогнозу кадрових потреб та способів оцінки праці персоналу, діагностики } \\
\text { кадрової ситуації; } \\
\text { - керівництво працює у режимі екстреного реагування на конфліктні ситуації, прагне } \\
\text { усунути їх будь-якими засобами без аналізу причин і можливих наслідків }\end{array}$ \\
\hline $\begin{array}{l}\text { 3.Реактивна } \\
\text { кадрова політика }\end{array}$ & $\begin{array}{l}\text { - керівництво підприємств здійснює контроль за симптомами негативного стану в робо- } \\
\text { ті з персоналом, причинами і ситуацією розвитку кризового стану; } \\
\text { - відсутність мотивації до високопродуктивної праці; } \\
\text { - кадрова служба має засоби діагностики ситуації, а за необхідності надає екстрену до- } \\
\text { помогу; } \\
\text { - труднощі виникають при середньостроковому прогнозуванні }\end{array}$ \\
\hline $\begin{array}{l}\text { 4.Превентивна } \\
\text { кадрова політика }\end{array}$ & $\begin{array}{l}\text { - керівництво підприємств має обгрунтовані прогнози розвитку кадрової ситуації, але не } \\
\text { має засобів впливу на неї; } \\
\text { - кадрова служба має не тільки засоби діагностики персоналу, а і прогнози кадрової си- } \\
\text { туації на середньостроковий період; } \\
\text { - головний недолік цієї політики - відсутність цільових кадрових програм }\end{array}$ \\
\hline $\begin{array}{l}\text { 5.Авантюристична } \\
\text { кадрова політика }\end{array}$ & $\begin{array}{l}\text { - керівництво не має якісного діагнозу кадрової роботи, але прагне впливати на ситуа- } \\
\text { цію; } \\
\text { - кадрова служба не має засобів прогнозування кадрової ситуації, але в програми розви- } \\
\text { тку організації включаються плани кадрової роботи, які не передбачають своєчасного } \\
\text { усунення можливих змін ситуації; } \\
\text { - плани будуються на емоціональних мало аргументованих заходах без попереднього та } \\
\text { всебічного розгляду, а при різких змінах ситуації на ринку виявляється нездатність } \\
\text { швидкого здійснення перенавчання персоналу для роботи в нових умовах, або залучен- } \\
\text { ня із зовнішніх джерел }\end{array}$ \\
\hline
\end{tabular}

*систематизовано автором за аналізом джерел [28]

Таблиця 3

Основні напрями кадрової політики за ступенем відкритості формування кадрового складу*

\begin{tabular}{|c|c|c|}
\hline & Відкрита кадрова політика & Закрита кадрова політика \\
\hline Напрями кадрової політики & $\begin{array}{c}\text { організація прозора для } \\
\text { співробітників на будь-якому } \\
\text { рівні при прийнятті як на низову } \\
\text { так і на керівну посади } \\
\end{array}$ & $\begin{array}{c}\text { зорієнтована на просування на вищі } \\
\text { посади тільки своїх працівників }\end{array}$ \\
\hline 1.Добір персоналу & $\begin{array}{l}\text { Прозора, на основі конкурсного } \\
\text { відбору при високій конкуренції } \\
\text { на ринку праці }\end{array}$ & $\begin{array}{l}\text { Проводиться із числа своїх праців- } \\
\text { ників в умовах дефіциту робочої } \\
\text { сили на ринку праці }\end{array}$ \\
\hline 2.Адаптація персоналу & $\begin{array}{l}\text { Працівники швидко включаються } \\
\text { в конкурентні відносини, впрова- } \\
\text { дження нових організаційних під- } \\
\text { ходів, запропонованих новачками }\end{array}$ & $\begin{array}{l}\text { Адаптація персоналу проводиться за } \\
\text { рахунок наставників }\end{array}$ \\
\hline 3.Навчання та розвиток персоналу & $\begin{array}{l}\text { Здійснюється у зовнішніх навча- } \\
\text { льних закладах, враховується дос- } \\
\text { від конкурентів }\end{array}$ & $\begin{array}{l}\text { Здійснюється у внутрішніх центрах } \\
\text { підготовки кадрів } 3 \text { урахуванням } \\
\text { загальної технології роботи підпри- } \\
\text { ємства }\end{array}$ \\
\hline 4.Просування по службі & $\begin{array}{l}\text { Недостатні можливості зростання } \\
\text { по службі }\end{array}$ & $\begin{array}{l}\text { Політика призначення на керівні } \\
\text { посади своїх працівників }\end{array}$ \\
\hline 5.Мотивація та стимулювання & $\begin{array}{l}\text { Перевага надається стимулювання } \\
\text { праці }\end{array}$ & Перевага надається мотивації праці \\
\hline 6.Впровадження новацій & $\begin{array}{l}\text { Нові працівники сприяють впро- } \\
\text { вадження інновацій }\end{array}$ & $\begin{array}{l}\text { Необхідність в ініціюванні процесу } \\
\text { інноваційної діяльності }\end{array}$ \\
\hline
\end{tabular}

\footnotetext{
*систематизовано автором за аналізом джерел [28]
} 
Прийняття рішень управлінським персоналом підприємства щодо формування кадрової політики здійснюється на підставі аналізу даних інформаційних джерел щодо кадрового забезпечення підприємства.

Система обліково-аналітичного забезпечення менеджменту підприємства об'єднує три взаємопов'язаних елементи: підсистему облікового забезпечення, підсистему аналітичного забезпечення та підсистему контролю [29]. Те саме можемо сказати і стосовно обліково-аналітичного забезпечення кадрової політики підприємств харчової промисловості. Але доказову базу кадрової політики, на наш погляд слід доповнити даними, які несуть дані про кадри підприємства, але не являються підставою для облікових записів, тобто інформаційним забезпеченням.

На наш погляд, обліково-аналітичне забезпечення кадрової політики підприємств харчової промисловості складається з таких видів забезпечення:

- нормативно-законодавче забезпечення;

- інформаційно-кадрове забезпечення;

- облікова інформація;

- аналітична інформація;

- результати внутрішньогосподарського контролю.

В табл. 4 систематизовано види доказів щодо кадрової інформації, джерел їх отримання та відповідні види забезпечення.

Таблиця 4

Інформаційно-кадрове забезпечення в системі кадрової безпеки [30]

\begin{tabular}{|c|c|c|}
\hline $\begin{array}{c}\text { Види доказів щодо кадрової } \\
\text { інформації }\end{array}$ & Джерела отримання доказів & Види забезпечень \\
\hline $\begin{array}{l}\text { 1.Докази трудового стажу та } \\
\text { страхового стажу }\end{array}$ & Трудова книжка & $\begin{array}{l}\text { Інформаційно-кадрове } \\
\text { забезпечення }\end{array}$ \\
\hline $\begin{array}{l}\text { 2.Докази інформації щодо } \\
\text { чисельності працюючих }\end{array}$ & Дані статистичної звітності & Облікова інформація \\
\hline $\begin{array}{l}\text { 3.Докази достовірності нара- } \\
\text { хування заробітної плати }\end{array}$ & $\begin{array}{l}\text { Облікові регістри по синтетичним рахункам } 3 \\
\text { обліку заробітної плати }\end{array}$ & Облікова інформація \\
\hline $\begin{array}{l}\text { 4.Докази руху кадрового } \\
\text { складу }\end{array}$ & $\begin{array}{l}\text { Особисті листки з обліку кадрів } \\
\text { Накази про рух кадрів (зарахування на роботу, } \\
\text { внутрішнє переміщення, догани, заохочення, під- } \\
\text { вищення, відпустку, звільнення тощо) }\end{array}$ & $\begin{array}{l}\text { Інформаційно-кадрове } \\
\text { забезпечення } \\
\text { Облікова інформація }\end{array}$ \\
\hline $\begin{array}{l}\text { 5.Докази кваліфікації праців- } \\
\text { ника }\end{array}$ & $\begin{array}{l}\text { Особисті листки з обліку кадрів } \\
\text { Документи працівника, що підтверджують рівень } \\
\text { освіти (диплом, сертифікат тощо) }\end{array}$ & $\begin{array}{l}\text { Інформаційно-кадрове } \\
\text { забезпечення } \\
\text { Облікова інформація }\end{array}$ \\
\hline $\begin{array}{l}\text { 6.Докази законності нараху- } \\
\text { вання та утримань із заробіт- } \\
\text { ної плати }\end{array}$ & $\begin{array}{l}\text { Нормативні акти (Податковий кодекс України, } \\
\text { Інструкції, Закони) } \\
\text { Колективний договір } \\
\text { Накази керівництва }\end{array}$ & $\begin{array}{l}\text { Інформаційно-кадрове } \\
\text { забезпечення }\end{array}$ \\
\hline $\begin{array}{l}\text { 7.Докази ефективності вико- } \\
\text { ристання трудового (кадрово- } \\
\text { го) потенціалу }\end{array}$ & Результати аналізу труда та заробітної плати & Аналітична інформація \\
\hline
\end{tabular}

Таким чином джерелом інформації, необхідної для прийняття управлінських рішень щодо формування та контролю виконання кадрової політики підприємства $є$ :

1. Інформація про умови праці, кваліфікацію та встановлені оклади, тарифи, розцінки.

2. Облікова інформація про нарахування заробітної плати.

3. Облікова інформація про утримання із заробітної плати та розрахунків по оплаті праці. ній платі.

4. Статистична звітність по труду та заробіт-

5. Аналітична інформація по ефективності використання кадрового потенціалу.
6. Податкова звітність про заробітну плату та рух кадрового складу.

Висновки та перспективи подальших досліджень. Формування обліково-аналітичного забезпечення кадрової політики, яке базується на надійній та достовірній обліковій інформації та даних аналізу, що дозволяє оперативно контролювати ефективність використання кадрів та рівень оплати праці, виявляти негативні тенденції і перспективні напрямки розвитку, стає вирішальною умовою формування якісної кадрової політики та забезпечення кадрової безпеки підприємства.

\section{Література}

1. Швець Н.К. Методи виявлення і збереження кадрової безпеки, або як перемогти зловживання персоналу [Електронний ресурс] / Н.К. Швець // Персонал. - 2006. - №5. - С.70-75. - Режим доступу:www.personal.in.ua/ 
69-73.

2. Царенко Ю. Позаботьтесь о кадровой безопасности / Ю. Царенко // Кадровое дело. - 2005. - №1. - С.

3. Живко З.Б. Кадрова безпека в системі економічної безпеки підприємства / З.Б. Живко // Вплив політичних циклів на якість життя та рівень щастя в Україні: Матеріали засідання круглого столу ; за ред. М.І.Флейчук, У.В. Щурко, Н.І. Черкас, О.Б. Василиці [Електронний ресурс] - Львів: «Сполом», 2013. - 127 с. Режим доступу: http://lv.niss.gov.ua/content/articles/files/Zbirnyk-29.03-19b69.pdf

4.Алавердов А. Р. Управление кадровой безопасностью организации: [учеб.] / А. Р. Алавердов. - М.: Маркет ДС, 2011. - 176 с.

5.Баглей Д.Ю. Технология кадрового менеджмента в системе экономической безопасности предпринимательства : автореферат диссертации на соискание ученой степени кандидата экономических наук : 08.00 .05 / Д.Ю. Баглей, Ростов-на- Дону, 2007. - 35 с.

6. Егоров С. С. Кадровая безопасность и топ-менеджмент предприятий / С. С. Егоров, М. Я. Корнилов // Инициативы XXI века. - 2010. - № 4 - 5. - С. $80-83$.

7.Гречішкіна А.А. Сутність поняття «кадрова безпека підприємств залізничного транспорту» / А.А.Гречішкіна. - Науковий вісник Херсонського державного університету. - Вип. 6, Частина 2. - 2014. C.144-146.

8. Экономическая и национальная безопасность: [учеб.] / под ред. Л. П. Гончаренко. - М.: Экономика, 2007. - $543 \mathrm{c}$.

9. Джобава А. М. Организационные и экономические составляющие конкурентоспособности предприятия / Джобава А. М. // Кадры предприятия. - 2009. -№ 1. - С. 10 -11.

10.Калініченко Л.Л. Методологічний підхід до управління персоналом підприємств залізничного транспорту в умовах реформування галузі: [монографія] / Л.Л. Калініченко. - Харків: УкрДАЗТ, 2012. - 382 с. C.219.

11.Кафидов В. В. Управление человеческими ресурсами: [учеб. пособие] / В. В. Кафидов. - СПб.: Питер, 2012. - $208 \mathrm{c}$.

12. Кибанов А. Я. Управление персоналом организации / А. Я. Кибанов. - М.: ИНФРА-М, 2002. - 638 с.

13.Кириченко О.А. Менеджмент зовнішньоекономічної діяльності: [навч. посіб.] / О.А. Кириченко. [3-те вид., перероб. і доп.]. - К.: Вид-во «Знання-Прес», 2002. - 384 с.

14. Лащенко О.Ю. Кадрова безпека як підсистема в системі економічної безпеки підприємства. Проблеми системного підходу в економіці [Електронний ресурс] / О.Ю. Лащенко. - К.: НАУ, 2007. - Вип. 4. - Режим доступу: http://archive.nbuv.gov.ua/ e-journals/PSPE/2007-3/Laschenko_307.htm.

15.Литовченко О.Ю. Формування кадрової безпеки підприємств АПК: автореферат дис. на здобуття наук. ступеня канд. екон. наук. : спец. 08.00.04 - «Економіка та управління підприємствами» (машинобудування, агропромисловий комплекс, туристичні підприємства та підприємства рекреаційного комплексу)» / О. Ю. Литовченко, Київ, 2010. - С. 22.

16. Логінова Н.І. Місце кадрової безпеки в економічній безпеці під- приємства / Н.І. Логовіна // Коммунальное хозяйство городов: научно-технический сборник. - 2009. - № 87. - С. 371-376.

17. Мехеда Н.Г. Соціально-мотиваційні складові кадрової безпеки / Н.Г.Мехеда, А.І.Маренич. - Фінансовий простір. - №2 (6), 2012. - С. 44-51.

18.Мойсеєнко І.П. Управління фінансово-економічною безпекою підприємства / І.П. Мойсеєнко, О.М. Марченко: [навч. посіб.]. - Львів, 2011. - 380 с.

19. Мирющенко А. Л. Теория кадровой безопасности. - 2007 [Электронный ресурс]: Кадровая безопасность как система. - Режим доступа: www. kadry.ucoz.ru

20. Митрофанов А. А. Экономическая безопасность коммерческих предприятий и деловая разведка. 2006 [Электронный ресурс]: Российское общество профессионалов конкурентной разведки. - Режим доступа: http://www.rscip.ru/base/A9738409- 3441822.

21. Назарова Г.О. Передумови створення системи кадрової безпеки підприємства / Г.О. Назарова // Регіональні аспекти розвитку продуктивних сил України. - Терноп. нац. екон. ун-т. - 2010. - Вип.15. - С. 34-37.

22. Петров М. І. Економічна безпека підприємства: сутність, трактування, точки зору / М. I. Петров // Менеджер. - 2002. - №1(17). - С. 67-71.

23. Чаплигіна Ю. С. Етимологічний аналіз категорії «кадрова безпека» / Ю. С. Чаплигіна // Управління розвитком. - 2011. - №4 (101). - С. 102-104.

24. Чумарин И. Г. Что такое кадровая безопасность компании? / И. Г. Чумарин // Кадры предприятия. 2003. - № 2. - С. 32-34.

25. Шаваев А.Г. Безопасность корпораций. Криминологические, уголовно-правовые и организационные проблемы / А.Г. Шаваев - М.: Банковский Деловой Центр, 2002. - 239 с.

26. Кадровая безопасность: [учебно-методич. пос.] / И.Р. Шегельман, М.Н. Рудаков. - Петрозаводск: ПетрГУ, 2006. - 96 с.

27.Мехеда Н.Г. Кадрова безпека як підсистема економічної безпеки підприємства [Електронний ресурс] / Н.Г. Мехеда, А.Мудь. - Режим доступу: www.rusnauka.com/33_DWS_2013/Economics/10_149832.doc.htm 
28.Виноградський М.Д. Управління персоналом в системі менеджменту організацій [навч. посіб.] / Виноградський М.Д., Виноградська А.М., Шканова О.М. - [2-ге вид.]. - К.: Центр учбової літератури, 2009. - 502 c.

29.Загородній А.Г. Система обліково-аналітичного забезпечення менеджменту підприємства / А.Г. Загородній // Вісник Нац. ун-ту «Львівська політехніка». Менеджмент та підприємництво в Україні: етапи становлення і проблеми розвитку. - Львів: вид-во Нац. ун-ту «Львівська політехніка». - 2007. - № 576. - С. 94-102.

30.Ткачук Г.О. Обліково-аналітичне забезпечення кадрової політики підприємства / Г.О. Ткачук, О.В. Щукіна // Обліково-аналітичне забезпечення в умовах управління фінансово-економічною безпекою підприємства: [монографія] / [В.В. Немченко, Ф.А. Трішин, Л.В. Іванченкова, Н.М. Купріна, Г.О. Ткачук та ін.] ; за заг. ред. д. е. н., проф. В.В. Немченко. - Одеса: Фенікс, 2015. - 360 с. - С. 31-45.

Стаття надійшла 29.06.2017

Стаття прийнята до друку 14.07.2017

Доступно в мережі Internet 30.09.2017

Ткачук Г.А.

кандидат экономических наук, доцент

кафедра учета и аудита

Одесская национальная академия пищевых технологий

ул. Канатная, 112, г. Одеса, Украина, 65039

E-mail: talla2007@ukr.net

\section{УЧЕТНО-АНАЛИТИЧЕСКОЕ ОБЕСПЕЧЕНИЕ КАДРОВОЙ БЕЗОПАСНОСТИ ПРЕДПРИЯТИЯ}

Проведена систематизация научных подходов к определению категории «кадровая безопасность». На основании анализа источников определен состав основных кадровых угроз в системе экономической безопасности предприятий пищевой промышленности.

Определено, что большое количество проблем в системе кадровой безопасности может быть ликвидирована или сведена к минимуму при наличии продуманной эффективной кадровой политики предприятия.

Систематизированы виды и основные направления кадровой политики. Выделены виды учетно-аналитического обеспечения кадровой политики.

Автор предлагает состав информационно-кадрового обеспечения экономической безопасности предприятия.

Определен перечень источников информации, необходимой для принятия управленческих решений по формированию и контролю выполнения кадровой политики предприятия.

Сделан вывод, что учетно-аналитическое обеспечение, которое позволяет оперативно контролировать эффективность использования кадров и уровень оплаты труда, выявлять негативные тенденции и перспективные направления развития, становится решающим условием фрормирования качественной кадровой политики и обеспечения кадровой безопасности предприятия

Ключевые слова: Ключевые слова: фринансово-экономическая безопасность, кадровая безопасность, учетно-аналитическое обеспечение, кадровые угрозы, кадровая политика, информационно-кадровое обеспечение.

Tkachuk G.

Ph.D., Associate Professor

Department of Accounting and Auditing

Odessa National Academy of Food Technologies

Kanatna str., 112 , Odessa, Ukraine, 65039

E-mail: talla2007@ukr.net

\section{ACCOUNTING AND ANALYTICAL SUPPORT OF PERSONAL SECURITY OF THE COMPANY}

The systematization of scientific approaches to the definition of the "personnel security" has been carried out. The composition of the main personnel threats in the system of economic safety of food industry enterprises has been determined on the basis of the analysis of the sources. 
We can refer to such threats the following: losses, connected, with staff turnover, confidential information leakage; mistakes due to low, qualification of employees; mistakes, connected with high degree of fatiguability and monotony of the labour, absence of scientific organization of labour; presence of professional diseases; lack of personal interest in the results of the work; absence of professional and carrer growth.

It has been determined that a large number of problems in the system of personnel security can be eliminated or minimized if there is considered effective personnel policy of the company.

The types and main directions of personnel policy have been systematized. The types of accounting and analytical support of personnel policy have been pointed out. The author suggests the composition of information and enterprise economic safety.

The author suggesta that the accounting and analytical support of the personnel policy of the food industry enterprises consists of the following types of provision: regulatory and legislative information; information and personnel support; accounting information; analytical information; results of internal control.

The list of sources of information needed for management decisions on the formation and control of personnel policy of the company has been determined.

It has been concluded that accounting and analytical software that allows you to quickly control the efficiency of personnel and wages, identify negative trends and future directions of development becomes the crucial condition of the formation of high-quality personnel policy and providing of personnel security of the company

Keywords: financial and economic security, personnel security, accounting and analytical support, human threats, personnel, information and personnel support.

\section{References}

1. Shvets, N. K. (2006). Metody vyiavlennia i zberezhennia kadrovoi bezpeky, abo yak peremohty zlovzhyvannia per-sonalu. Personal, 5, 70-75. Retrieved from www.personal.in.ua/.

2. Tsarenko U. (2005). Pozabottes o kadrovoi bezopasnosty . Kadrovoe delo, 1, 69-73.

3. Zhyvko , Z. B. (2013). Kadrova bezpeka v systemi ekonomichnoi bezpeky pidpryiemstva. Lviv: Spolom.

4. A. R., Alaverdov . Upravlenye kadrovoi bezopasnostiu orhanyzatsyy (Vol. 2011). M.: Alaverdov.

5. Bahlei, D. I. (2007). Tekhnolohyia kadrovoho menedzhmenta v systeme эkonomycheskoi bezopasnosty predpryny-matelstva. Rostov-na- Donu: D.Iu. Bahlei. Received 29 October 2016

6. Ehorov, S. S. (2010). Kadrovaia bezopasnost y top-menedzhment predpryiatyi . Ynytsyatyvы XXI veka, 4 $-5,80-83$.

7. Hrechishkina, A. A. (2014). Sutnist poniattia «kadrova bezpeka pidpryiemstv zaliznychnoho transportu». Naukovyi visnyk Khersonskoho derzhavnoho universytetu, (6), 2nd ser., 144-146.

8. Honcharenko, L. P. (2007). Эkonomycheskaia y natsyonalnaia bezopasnost. M.: Эkonomyka.

9. Dzhobava, A. M. (2009). Orhanyzatsyonnыe y эkonomycheskye sostavliaiushchye konkurentosposobnosty predpryiatyia . Kadro predpryiatyia, 1, 10-11.

10. Kalinichenko , L. L. (2012). Metodolohichnyi pidkhid do upravlinnia personalom pidpryiemstv zaliznychnoho tran-sportu v umovakh reformuvannia haluzi. Kharkiv: UkrDAZT.

11. Kafydov , V. V. (2012). Upravlenye chelovecheskymy resursamy. Pyter: SPb.

12. Kybanov , A. I. (2002). Upravlenye personalom orhanyzatsyy . M.: YNFRA-M.

13. Kyrychenko , O. A. (2002). Menedzhment zovnishnoekonomichnoi diialnosti. K.: Vyd-vo «Znannia-Pres».

14. Lashchenko, O Iu. (2007). Kadrova bezpeka yak pidsystema v systemi ekonomichnoi bezpeky pidpryiemstva. Problemy systemnoho pidkhodu v ekonomitsi , 4.

15. Lytovchenko , O. I. (2010). Formuvannia kadrovoi bezpeky pidpryiemstv APK. Kyiv.

16. Lohinova, N. I. (2009). Mistse kadrovoi bezpeky v ekonomichnii bezpetsi pid- pryiemstva . Kommunalnoe khoziaistvo horodov: nauchno-tekhnycheskyi sbornyk, 87, 371-376.

17. Mekheda , N. H. (2012). Sotsialno-motyvatsiini skladovi kadrovoi bezpeky . Finansovyi prostir, 2(6), 4451.

18. Moiseienko , I. P. (2011). Upravlinnia finansovo-ekonomichnoiu bezpekoiu pidpryiemstva. Lviv.

19. Myriushchenko, A. L. (2007). Teoryia kadrovoi bezopasnosty.Kadrovaia bezopasnost kak systema.

20. Mytrofanov , A. A. (2006). Эkonomycheskaia bezopasnost kommercheskykh predpryiatyi y delovaia razvedka. Retrieved August 18, 2017, from Rossyiskoe obshchestvo professyonalov konkurentnoi razvedky. - Rezhym dostupa: http://www.rscip.ru/base/A9738409-3441822.

21. Nazarova, G. O. (2010). Peredumovy stvorennia systemy kadrovoi bezpeky pidpryiemstva . Rehionalni aspekty rozvytku produktyvnykh syl Ukrainy, 15, 34-37. $1(17), 67-71$.

22. Petrov, M. I. (2002). Ekonomichna bezpeka pidpryiemstva: sutnist, traktuvannia, tochky zoru . Menedzher,

23. Chaplyhina, Iu. S. (2011). Etymolohichnyi analiz katehorii «kadrova bezpeka». Upravlinnia rozvytkom, $4(101), 102-104$. 
24. Chumaryn , Y. H. (2003). Chto takoe kadrovaia bezopasnost kompanyy? . Kadry predpryiatyia, 2, 32-34.

25. Havaev , A. H. (2002). Bezopasnost korporatsyi. Krymynolohycheskye, uholovno-pravovыe y orhanyzatsyon-nыe problemы. M.: Bankovskyi Delovoi Tsentr.

26. Shehelman, Y. R. (2006). Kadrovaia bezopasnost:. Petrozavodsk: PetrHU.

27. Mekheda , N. H.. Kadrova bezpeka yak pidsystema ekonomichnoi bezpeky pidpryiemstva .

28. Vynohradskyi , M. D. (2009). Upravlinnia personalom v systemi menedzhmentu orhanizatsii . K.: Tsentr uchbovoi literatury.

29. Zahorodnii, A. H. (2007). Systema oblikovo-analitychnoho zabezpechennia menedzhmentu pidpryiemstva . Visnyk Nats. un-tu «Lvivska politekhnika»enedzhment ta pidpryiemnytstvo v Ukraini: etapy stanovlennia i problemy rozvytku, 576, 94-102.

30. Tkachuk, H. O., Shchukina, O. V., Nemchenko, V. V., \& Trishyn, F. A. (2015). Oblikovo-analitychne zabezpechennia kadrovoi polityky pidpryiemstva.Oblikovo-analitychne zabezpechennia $\mathrm{v}$ umovakh upravlinnia finansovo-ekonomichnoiu bezpekoiu pidpryiemstva. Odesa: Feniks.

Received 29 June 2017

Approved 14 July 2017

Available in Internet 30.09.2017 